\title{
EU's investment for health and viral diseases in poor countries
}

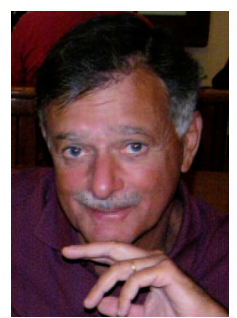

\author{
“...the EU's plan for health development \\ cooperation, despite strong investment and \\ considerable spending ... should reposition itself \\ towards better coherence and more coordination \\ and collaboration with interested parties."
}

\section{Daniele Dionisio}

European Parliament Working Group on Innovation, Access to Medicines \& Poverty-Related Diseases, Italian Society for Infectious \& Tropical Diseases, Research Project Geopolitics, Public Health \& Access to Medicines, Florence, Italy = d.dionisio@tiscali.it

Just under 3 billion people in developing countries live on less than US $\$ 2$ per day, meaning key medicines protected by patents are unaffordable [1].

Although people in these countries bear $90 \%$ of the global disease burden, only $10 \%$ of worldwide expenditure on health is used to address these diseases. As a result, viral, bacterial and protozoal infections, such as HIV/AIDS, measles, polio, dengue, pneumonia, malaria, TB, sleeping sickness, leishmaniasis and diarrheal diseases, among others, kill nearly 5 million people every year. More than a third of all deaths in low income countries occur among children under the age of 15 years [2].

These diseases are termed 'poverty-related' or 'neglected' (PRNDs) because they exist in the poorest and most marginalized settings.

Public funding from the world's richest nations for research and development (R\&D) of products for PRNDs fell by $\$ 125$ million (down $6 \%$ ) in 2010. As a result, R\&D for appropriate preventive, diagnostic and treatment tools are ailing [3].

This gap is compounded by international policies and free-trade deals backing the interests of the brand pharmaceutical sector while putting the trade of legitimate generic medicines at risk [4-6].

At a time when India's obligations to the World Trade Organization (WTO) prevent local companies from making generics for medicines introduced since 2005, these developments threaten the supply of generic medicines from India that serve as a lifeline to resource-limited countries $[7,8]$.

In this context, the EU's plan for health development cooperation, despite strong investment and considerable spending, seemingly lacks adequate coherence, innovative financing, coordination and collaboration with interested parties.

\section{Growing impact, but flaws persist}

The EU is a strong supporter of PRND R\&D, with the European Commission and Member State governments contributing almost a quarter (22\%) of government PRND R\&D investment worldwide and $15 \%$ of total global investment [9].

Funding also goes to the unique EDCTP (European and Developing Countries Clinical Trials Partnerships) mechanism, which successfully funds clinical trials in Africa for HIV/AIDS, TB and malaria, the performance of which would improve should more PRNDs and an expansion of scope beyond Africa be included.

The EU is also a key supporter of the Global Polio Eradication Initiative, together with the WHO, UNICEF, the US CDC and the Gates Foundation, among others [10].

Collectively, the EU supports research into 31 PRNDs, with three-quarters of funding (76\%) going to three diseases - HIV/ AIDS, TB and malaria. Research focuses on almost 150 PRND products in development ( $40 \%$ of all products in the pipeline), including new TB vaccines, malaria drugs that are safe for pregnant women, and vaccines for malaria, dengue fever and HIV.

Overall, R\&D for PRNDs is a priority in the EU Research Framework Programme 'Horizon 2020', as an opportunity for the Union to stimulate innovation and address the relevant financing and market failure [1].

However, the EU's commitment in PRND $\mathrm{R} \& \mathrm{D}$ is still not large enough (only $0.0024 \%$ of the EU's combined gross domestic product [GDP]), and is not spread evenly between Member States. Sweden, Ireland and the UK are investing over $0.0045 \%$ of their GDP, while others such as Finland and Italy contribute less

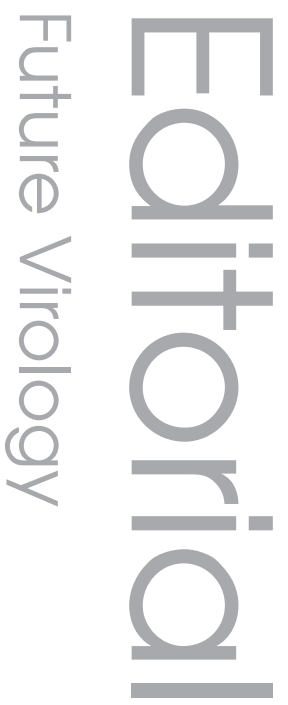

\section{Keywords}

- European Union

- health cooperation

- resource-limited populations

- viral diseases

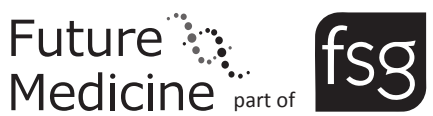


than a tenth as much $(0.0004$ and $0.0002 \%$ of their GDP, respectively). Additionally, Germany has only recently increased its commitments from its initial $0.0007 \%$ GDP investment [9].

66

"...closer EU collaboration with the WHO is to be hoped for..."

This aligns with figures showing that as a whole Europe's performance in development cooperation needs improving. In a recently published 2012 Commitment to Development Index by the Center for Global Development, Denmark, Norway and Sweden were on top (just before Luxembourg, Austria, the Netherlands and Finland), the UK was ninth, and Germany, Belgium, France and Spain took the 12th to 15 th slots (while Italy ranked 20 and Poland 25). Europe's overall global position of third in the ranking, after New Zealand and Canada, was attributed to the European countries' poor performance on the index and the EU's restrictive trade policies [12]. Furthermore, the EU's plan looks like it would lack the adequate collaboration and coordination with concerned parties.

As such, the latest WHO and EU plans to address medicine quality issues have raised criticisms of inadequate coordination and collaboration with one another [13]. Relevantly, the Directive 2011/62/EU (applicable on 2 January 2013) does not mention the $\mathrm{WHO}$ as a partner body for field purposes, and did not align with the WHO's definition of 'falsified medicines' [14].

Moreover, closer collaboration is awaited regarding the Global Fund to Fight AIDS, Tuberculosis and Malaria. Although the global fund was among the top recipients of EU contributions in 2011 (€65 million), EU support should increase now that the global fund faces a serious funding crisis, taking advantage of an unprecedented opportunity for the EU to demonstrate solidarity and join forces in the campaign against HIV, TB and malaria [15].

Similar considerations apply to the operational models the WHO has called for to finance R\&D for diseases of the poor and to ensure long-term access to medicines [16].

There is seemingly poor attention paid by the EU to a number of models taken into consideration by the WHO, disregarding evidence that any one model is not enough to ensure the full availability of life-saving medicines.
This is why closer EU collaboration with the WHO is to be hoped for, if a combination of two or more models is needed to ensure that the outputs of $R \& D$, innovation and access are available without restriction [17]. Since the foundation of all models is sustainable financing mechanisms, the EU must find novel funding sources for more engagement from the private sector at this time of global economic slump and budget constraints.

In this regard, the quorum for a Financial Transaction Tax (FTT) has been reached in the EU under the 'enhanced cooperation' procedure, a mechanism which allows a group of at least nine EU countries to move forward on an issue that fails to gather the required majority [18].

The FTT would apply to any transaction in financial instruments, excluding primary market issuance and bank loans. Share and bond transactions would be taxed at $0.1 \%$ of the higher of consideration and market value and derivatives at $0.01 \%$ of their notional amount [19].

“...the EU must find novel funding sources for more engagement from the private sector at this time of global economic slump and budget constraints."

As such, a FTT would be up to the task, provided that the EU, following France's example, will commit "at least $10 \%$ of its revenues to development and for the fight against health scourges and pandemics" [20].

\section{Filling the gaps is 'sine qua non' for leadership}

Filling the gaps highlighted here would allow the EU to gain sound leadership in global health.

To this aim, the EU should reposition itself towards better coherence between policies, strategies and practices.

While helping address a highly fragmented landscape and identifying shared global priorities for health, these actions would fully align with the 2010 EU Commission Communication and Council conclusions on the EU role in Global Health:

"At global level, the EU should endeavour to defend a single position within the UN agencies. The EU should work to ... increase coordination and effectiveness of the UN system. It should support stronger leadership by the WHO in its normative and guidance functions to improve global health. The EU should seek synergies with WHO to address global health challenges..." [21]. 
"The EU shall promote dialogue and joint action with key global players and stakeholders, including UN agencies concerned with global health, International Financing Institutions, regional organisations, regional health networks, and countries, in order to identify synergies, coordinate actions, advance in the achievement of commitments, and avoid duplication and fragmentation to increase effectiveness" [22].

\section{Financial \& competing interests disclosure}

The author has no relevant affiliations or financial involvement with any organization or entity with a financial interest in or financial conflict with the subject matter or materials discussed in the manuscript. This includes employment, consultancies, honoraria, stock ownership or options, expert testimony, grants or patents received or pending, or royalties.

No writing assistance was utilized in the production of this manuscript.

\section{Websites}

1. WHO. Sixty-first World Health Assembly. http://apps.who.int/gb/ebwha/pdf_files/A61/ A61_R21-en.pdf (Accessed 24 May 2008)

2. Call to EU leadership on global health R\&D. www.action.org/documents/CALL_TO_EU_ LEADERSHIP_ON_GLOBAL_HEALTH_ RD.pdf (Accessed 30 September 2012)

3. Research and Development for poverty-related and neglected diseases.

www.tbvi.eu/fileadmin/user_upload/

Documenten/Overig/TBEC_position_paper_ Horizon_2020.pdf

(Accessed 28 February 2012)

4. International Centre for Trade and Sustainable Development. New Delhi, Brussels expect Autumn trade deal. http://ictsd.org/i/news/bridgesweekly/125538/ (Accessed 15 February 2012)

5. Intellectual Property Watch. EU-India summit kicks off amidst warnings of impact on medicines access.

www.ip-watch.org/2012/02/10/eu-indiasummit-kicks-off-amidst-warnings-of-impacton-medicines-access

(Accessed 10 February 2012)

6. Medecins Sans Frontieres. Blank cheque for abuse: ACTA \& its impact on Access to Medicines.

www.msfaccess.org/content/acta-and-itsimpact-access-medicines

(Accessed 28 February 2012)

7. World Trade Organization. Agreement on trade-related aspects of intellectual property rights.

www.worldtradelaw.net/uragreements/ tripsagreement.pdf

(Accessed 31 October 2012)
8. Medecins Sans Frontieres. New report highlights India's role as 'lifeline' for patients in developing countries.

www.msfaccess.org/our-work/hiv-aids/ article/1598

(Accessed 31 October 2012)

9. DSW and Policy Cures. EU investment in poverty-related neglected diseases. www.dsw-online.org/fileadmin/user_ upload_en/PDF/GH_R_D_EU/Saving _ Lives_and_Creating_Impact_DSW-PC Report.pdf

(Accessed 30 September 2012)

10. Global Polio Eradication Initiative. www.polioeradication.org (Accessed 31 October 2012)

11. European Commission. Horizon 2020. http://ec.europa.eu/research/horizon2020/ index_en.cfm

(Accessed 31 October 2012)

12. Center for Global Development. 2012 commitment to development index. www.cgdev.org/section/initiatives/_active/ cdi

(Accessed 31 October 2012)

13. Intellectual Property Watch. WHO/EU 'Bad medicine' plans: flaws, coordination gaps.

www.ip-watch.org/2012/04/02/who-eu$\%$ e2\%80\%9cbad-medicine $\%$ e $2 \% 80 \% 9$ dplans-flaws-coordination-gaps (Accessed 2 April 2012)

14. Official Journal of the European Union, Volume 54 http://eur-lex.europa.eu/JOHtml.do?ur i=OJ:L:2011:174:SOM:EN:HTML (Accessed 1 July 2011)

15. Devex. A good support system? www.devex.com/en/news/79417/print (Accessed 11 October 2012)
16. Intellectual Property Watch. WHO expert group to recommend binding $R \& D$ treaty negotiation.

www.ip-watch.org/2011/12/14/who-expertgroup-to-recommend-binding-rd-treatynegotiation

(Accessed 14 December 2011)

17. SciDev.net. Use new funding models to get drugs to world's poor.

www.scidev.net/en/health/access-tomedicine/opinions/use-new-funding-modelsto-get-drugs-to-world-s-poor-.html (Accessed 5 April 2012)

18. Euinside. After all the FTT will be introduced, though not across the entire EU. www.euinside.eu/en/news/after-all-the-fttwill-be-introduced-though-not-across-the-eu (Accessed 10 October 2012)

19. EurActive. France wants FTT in place 'before the end of the year'. www.euractiv.com/euro-finance/francepushes-ftt-year-news-514989 (Accessed 25 September 2012)

20. UNITAID. Calls for adoption of financial transaction tax as way forward for global development. www.unitaid.eu/index.php?option $=\mathrm{com}_{-}$ content\&view=article\&id $=1001$ (Accessed 26 September 2012)

21. European Commission. The EU role in global health.

http://ec.europa.eu/development/icenter/ repository/COMM_PDF_ COM_2010_0128_EN.PDF (Accessed 31 March 2010)

22. EU Council conclusions on the $\mathrm{EU}$ role in Global Health. www.eu-un.europa.eu/articles/en/ article_9727_en.htm (Accessed 10 May 2010) 